\title{
Activities of occupational nurses working in companies
}

\author{
Atividades de enfermeiros do trabalho atuantes em empresas
}

Daniela Inês Thier Roloff ${ }^{1}$, Marta Regina Cezar-Vaz ${ }^{1}$, Clarice Alves Bonow ${ }^{2}$, Marlise Capa Verde Almeida de Mello ${ }^{1}$

Objective: to understand the activities of occupational nurses working in companies. Methods: qualitative study, with eight occupational nurses working in seven companies. Data collected through interviews and non-participant observations analyzed by the Content Analysis method. Results: nurses perform activities of assistance, administrative, educational and integrative research, where the purpose of these traverses the approach to the worker and is interfered by the characteristics of the occupational health service and the institutional context. Conclusion: the work of nurses is influenced by the size of the health and safety team and the socioeconomic characteristics of companies and municipalities, shaping the labor market and posing a challenge for these professionals.

Descriptors: Occupational Health; Occupational Health Nursing; Occupational Health Services; Activities of Daily Living.

Objetivo: compreender as atividades de enfermeiros do trabalho atuantes em empresas. Métodos: estudo qualitativo, com oito enfermeiros do trabalho atuantes em sete empresas. Dados coletados através de entrevistas e observações não participantes e analisados pelo método de Análise de Conteúdo. Resultados: os enfermeiros realizam atividades de cunhos assistencial, administrativo, educativo, integrativo e de pesquisa, onde a finalidade dessas perpassa o enfoque ao trabalhador e é interferida pelas características do serviço de saúde ocupacional e pelo contexto institucional. Conclusão: a atuação dos enfermeiros do trabalho é influenciada pelo dimensionamento da equipe de saúde e segurança e pelas características socioeconômicas das empresas e dos municípios, moldando o mercado de trabalho e colocando-se como desafio para esses profissionais.

Descritores: Saúde do Trabalhador; Enfermagem do Trabalho; Serviços de Saúde do Trabalhador; Atividades Cotidianas.

\footnotetext{
${ }^{1}$ Universidade Federal do Rio Grande. Rio Grande, RS, Brazil.

${ }^{2}$ Universidade Federal de Pelotas. Pelotas, RS, Brazil. 


\section{Introduction}

The area of workers' health constitutes an interdisciplinary and multi-institutional domain, where work is considered one of the main social determinants of health. It advocates an integrative vision that includes health promotion, disease prevention and curative care of the worker, through actions of vigilance in workers' health, which has as axes of action the causes or determinants of the diseases, risks or exposure and damages or consequences, with physical, social or psychological impairment ${ }^{(1-2)}$.

In the business scenario, attention to workers' health is provided by the Specialized Service in Safety Engineering and in Occupational Medicine, recommended by Regulatory Norm $4^{(3)}$, which establishes a multidisciplinary and interdisciplinary team to assist the worker, composed of professionals (work safety engineer, occupational safety technician, assistant or technician in occupational nursing, occupational physician and occupational nurse). Its sizing is influenced by the degree of risk of the main activity of the company (1 to 4 ) and the total number of employees.

The occupational nursing, considered a part of work in this area of action, was originally known as "industrial nursing", its evolution occurred during the Industrial Revolution. Over the years, it has assumed a variety of functions, giving nurses the care of workers in various workplaces ${ }^{(2)}$, having expanded in Brazil since the $1950 \mathrm{~s}^{(4)}$.

The occupational nurse has as profile, the execution of activities related to the service of hygiene, medicine and work safety, integrating study teams, to provide health preservation and valorization of the worker ${ }^{(5)}$. It has rules that define and establish care standards, which describe the health professional's responsibility and reflect the values and priorities of the profession, such as health assessment, diagnosis, results identification, planning, implementation, evolution, resource management, professional development, collaboration, research and ethics ${ }^{(6)}$.

The activities of these nurses are divided by areas, such as care (nursing process aimed at meeting the needs of promotion, protection and recovery of workers' health); (tasks related to the planning, organization, direction, coordination and evaluation of activities in the area); (activities related to the education of workers and members of the nursing team at work); of integration (stimulating workers, business and class entities to fight for causes of common interest) and research (studies and ongoing investigations that contribute to the improvement of knowledge and professional practice) ${ }^{(7)}$.

Therefore, it is questioned what are the activities of occupational nurses working in the occupational health services of the companies represented in this study, considering the historical context of insertion of such specialty in the health care of the worker, the different branches of economic activities of these companies And the division of its activities into different areas. Therefore, the objective of this study is to understand the activities of work nurses working in companies.

\section{Methods}

The study was attended by eight occupational nurses working in the Specialized Services in Safety Engineering and Occupational Medicine of seven companies located in two municipalities of the Southern Macro-region of Rio Grande do Sul, Brazil. A Letter of Presentation of the Study was sent to all those companies that had the professional occupational nurse work in their staff of collaborators, who informed later its acceptance. Thus, the group of participants was composed of all occupation nurses working in companies in the Southern Macro-region, of Rio Grande do Sul, Brazil.

These companies represent several branches of economic activity and were classified according to the National Classification of Economic Activities ${ }^{(8)}$ : four companies as transformation industries, represented by one of the construction sector of large vessels, one of manufacturing of products derived from oil refining 
and two from the compost and fertilizer manufacturing area; a company of electricity and gas activity, represented by the generation of electric energy; a company of transportation, warehousing and mail activity, represented by terminal operations and another classified as water, sewage, waste management and decontamination activities, represented by the collection, treatment and distribution of water.

Data were collected between January and April 2015, based on a semi-structured script. Pilot interviews were conducted with three occupational nurses who were not part of the group of participants, to test the understanding and to make the quality of the interview script viable. After this stage, the interviews were carried out with prior scheduling at the nurses' workplace, ranging from 90 to 190 minutes, with an average of 122 minutes.

In addition, non-participant observations were made after the conclusion of the interviews with each nurse in their workplace, to understand in detail the work process of each one and to complement the results of the research. A total of 74 hours and 25 minutes were observed, with an average of eight hours and two minutes of observation of each nurse.

Data analysis was made using the content analysis method ${ }^{(9)}$, of the thematic, categorical and frequency type. The five categories of analysis were systematized based on the five different areas of activities of occupational nurses: care, administrative, educational, integrative and research ${ }^{(7)}$. The thematic units of each category were constituted in the action of the professionals through the activities, the context units by the purpose of these activities and the registration units constituted by the examples of activities that approached the action and purpose.

Finally, in the treatment phase of the results and interpretation, the results were presented through thematic units, context units and registration units, in which the absolute frequency (n) was added, regarding the number of nurses who referred each unit of record $\left(n_{e}\right)$ and the number of observations $\left(n_{0}\right)$, in addition to the use of their statements.
Participants were identified by the letter $\mathrm{E}$ and the number corresponding to the company ( 1 to 7 ), and the two nurses representing the company 7 had the numbers 1 and 2 added.

The study complied with the formal requirements contained in the national and international regulatory standards for research involving human beings.

\section{Results}

The group of participants in the study comprised eight female nurses, with a predominance of females $(n=6)$, between the ages of 31 and 40 years $(n=4)$ and married/stable marriages $(n=4)$. The highest professional qualification was the specialization $(n=7)$, working time in the sector from 1 to 5 years $(n=4)$, monthly income from $R \$ 3,001.00$ to $R \$ 5,000.00$ (reals) $(n=5)$ and weekly workload from 30 to 40 Hours $(n=6)$. Each branch of economic activity was represented by a nurse, except for the capture, treatment and distribution of water, represented by two. Of the companies represented in this survey, three have up to 100 employees, two have from 1,001 to 3,500 employees and three companies have 3,501 to 8,000 employees.

\section{Activities of assistance}

The statements and observations of the eight nurses about their care activities constituted a thematic unit - Care Activities - and three units of context: Health Promotion, Prevention of the diseases and Health Recovery.

The unit of record linked to the first unit of context was: verification of vital signs $\left(n_{e}=5, n_{0}=2\right)$. The unit of record linked to the second unit of context was: monitoring of workers in confined room and height $\left(n_{e}=4, n_{0}=2\right)$. On the other hand, the units of record linked to the third unit of context were: Treatment of wounds and injuries $\left(\mathrm{n}_{\mathrm{e}}=4, \mathrm{n}_{\mathrm{o}}=2\right)$, medication administration $\left(\mathrm{n}_{\mathrm{e}}=3, \mathrm{n}_{\mathrm{o}}=1\right)$ and urgency emergency care, 
$\left(\mathrm{n}_{\mathrm{e}}=3, \mathrm{n}_{\mathrm{o}}=1\right)$. Verification of blood pressure, dressings, intramuscular and oral medication. (E2). We check blood pressure for those workers who will access confined room and height (E4).

During the observations, there was a predominance in the performance of technical procedures by nurses, such as blood pressure verification to release the workers in confined room and height, as well as the spontaneous demand of workers in the occupational health service, requesting the verification of blood pressure due to complaints of headache due to exposure to the sun heat at work. Also, a dressing change was observed by a nurse in a worker with a hand injury due to work accident.

\section{Administrative activities}

Regarding the activities of administrative professionals, the statements and observations of the eight nurses made it possible to establish a thematic unit called administrative activities and four units of context: direction, organization, planning and coordination.

The units of record linked to the first context unit were: Occupational Health medical Control Program $\left(n_{e}=8, n_{o}=7\right)$, occupational health service $\left(n_{e}=2\right.$, $\mathrm{n}_{\mathrm{o}}=7$ ) and monitoring of incidents/accidents of work. $\left(n_{\mathrm{e}}=2, \mathrm{n}_{\mathrm{o}}=3\right)$. The unit of record linked to the second unit of context was: workers' medical record $\left(n_{e}=7\right.$, $\left.n_{0}=4\right)$. The unit of record linked to the third unit of context was: material resources $\left(n_{e}=3, n_{o}=1\right)$. The unit of record linked to the fourth unit of context was: nursing team $\left(\mathrm{n}_{\mathrm{e}}=3, \mathrm{n}_{\mathrm{o}}=4\right)$. Managing the sector is what I do most today; it is the issue of support, support and organization of the sector (E1). What we do in the administrative part, which organizes really, is the control of the periodic exams... Then the control of the exams already done is passed to the spreadsheets, the exams are released in the portal (E3). So I think the management area is both personal and professional, of quality, medication, organization and vacation (E6).

During the period of observations, there were also activities related to the implementation of the Occupational Health Medical Control Program, such as the daily organization of documents required for occupational medical appointments, handling of the worker's medical record and the release of occupational health information in the computerized systems of the companies.

\section{Educational Activities}

The educational activities of the nurses, their statements and observations constituted a thematic unit - educational activities - and three units of context: health promotion, disease prevention and permanent education in nursing.

The units of record linked to the first unit of context were: occupational health campaigns $\left(\mathrm{n}_{\mathrm{e}}=4\right.$, $\left.\mathrm{n}_{\mathrm{o}}=1\right)$, daily health and safety dialogues $\left(\mathrm{n}_{\mathrm{e}}=3, \mathrm{n}_{\mathrm{o}}=0\right)$ and printed educational material $\left(\mathrm{n}_{\mathrm{e}}=2, \mathrm{n}_{\mathrm{o}}=3\right)$. The units of record linked to the second unit of context were: internal week of accident prevention $\left(n_{e}=4\right.$, $\left.\mathrm{n}_{\mathrm{o}}=0\right)$, training according to legislation $\left(\mathrm{n}_{\mathrm{e}}=2, \mathrm{n}_{\mathrm{o}}=1\right)$, occupational exams $\left(\mathrm{n}_{\mathrm{e}}=1, \mathrm{n}_{\mathrm{o}}=5\right)$ and vaccination $\left(n_{e}=1, n_{o}=0\right)$. However, the units of record linked to the third context unit were: internal activities $\left(\mathrm{n}_{\mathrm{e}}=3\right.$, $\left.\mathrm{n}_{\mathrm{o}}=2\right)$ and external events $\left(\mathrm{n}_{\mathrm{e}}=3, \mathrm{n}_{\mathrm{o}}=0\right)$. I participate in the Five-Minute Safety Program, once a month; we visit the areas, defined by a schedule made by Human Resources. ... I also participate in the courses provided by the Fire Brigade, always participating in the campaigns (E3). When there comes some nursing congress, some course, seminar, the company releases us (E7/2).

Some of the educational activities were observed, such as health orientations for the worker in the occupational health service and training, given by a nurse on first-aid to workers confined room and height.

\section{Integrative activities}

The integrative activities of the nurses comprised a thematic unit called Integrative Activities and three contextual units: work organization, prevention of injuries and rights and labor duties, based on the statements and observations of the health professionals. 
The units of record linked to the first unit of context were: outsourced companies $\left(n_{\mathrm{e}}=6, \mathrm{n}_{\mathrm{o}}=4\right)$ and sectors of the company $\left(n_{e}=4, n_{o}=6\right)$. The units of record linked to the second unit of context were: integration of hired workers $\left(\mathrm{n}_{\mathrm{e}}=4, \mathrm{n}_{\mathrm{o}}=1\right)$ and Mutual Assistance Plan $\left(n_{e}=2, n_{o}=0\right)$. The unit of record linked to the third unit of context was: Unions $\left(\mathrm{n}_{\mathrm{e}}=4, \mathrm{n}_{\mathrm{o}}=0\right)$. We have a weekly meeting with all the managers or people responsible for the outsourced companies (E1). One of the activities of integrative nature is the participation in the integration that is carried out here in the company. ... I am also part of the Mutual Assistance Plan, we participate in the meetings, and all the companies here in the industrial district participate (E3).

In the observations, the integration of the nurses with the staff of the Specialized Service in Safety Engineering and in Occupational Medicine, especially the health professionals, who work in the same work environment, besides the other sectors of the companies, such as administration, in organizational meetings, human resources, due to records of absenteeism, and production, for all assistance provided to workers' health.

\section{Research activities}

In relation to nurses' research activities, a thematic unit was created called Activities of Research and Investigation and two units of context: Generation of Health Indicators And Health Promotion, based on the statements and observations of the professionals.

The unit of record linked to the first unit of context was: periodic reports on occupational health $\left(n_{e}=6, n_{o}=7\right)$. The unit of record linked to the second unit of context was: monitoring of workers with chronic diseases (hypertensive, diabetic, cardiac patients) $\left(\mathrm{n}_{\mathrm{e}}=2, \mathrm{n}_{\mathrm{o}}=1\right)$. We conducted data collection on health; we used extensively in the hypertensive and diabetes cases, through the occupational health exams of the periodicals (E4). We withdrew this annual report and found from this annual report that the most prominent cases were musculoskeletal disease, sick leave (E6).

During the observations, the involvement of nurses in the generation of occupational health reports was registered, mainly in the services and indicators of the service, in addition to the occupational examinations of the workers.

\section{Discussion}

The study had as limitations, the delimitation of the geographic region of insertion of the companies, with small and medium size profile, which ended up constituting a group with reduced number of occupational nurses. Thus, it is suggested to carry out new studies with characteristics related to the profile of companies and professionals, which makes it possible to compare the results already found.

The contribution of the study to the construction of scientific knowledge in worker's health and occupational nursing is highlighted, while encompassing their performance through the activities carried out in the occupational health services of companies gives more visibility to their profession. Also, it allows nurses to analyze their work in the institutions, in order to reflect on their strengths and weaknesses as part of an interdisciplinary team in the health care of the worker. More than half of the nurses $(n=5)$ work in companies with less than 3,500 workers, which shows that, although not mandatory according to the legislation $^{(3)}$, this insertion suggests an association with the recognition of their specific professional skills and competences, management of occupational health services and the nursing team, in accordance with the law of professional nursing practice ${ }^{(10)}$, as well as the contribution in qualifying the interdisciplinary team that assists the worker.

More than half of the nurses $(n=5)$ work in companies with less than 3,500 workers, which shows that, although not mandatory according to the legislation ${ }^{(3)}$, this insertion suggests an association with the recognition of their specific professional skills and competences, management of occupational health services and the nursing team, in accordance with the 
law of professional nursing practice ${ }^{(10)}$, as well as the contribution in qualifying the interdisciplinary team that assists the worker.

Still, these characteristics are reflected by the economic scenario of the municipalities of insertion of the companies, since, although they stand out for their productive development in the region, they are still small and medium-sized companies that interfere directly in the labor market for the work of occupational nurses.

In the history of organizations, people with their skills and talents have never been as valued as they are today ${ }^{(11)}$. In addition, changes in business management, sales policy, customer acquisition and maintenance, and the incorporation of new technologies have led to new forms of production management and personnel management, with new tasks and new requirements for workers in the development of labor activity $^{(12)}$. In this sense, the occupational nurse can be seen and valued for his/her competencies regarding the health of the worker, in a context of complexity of the modes of production and economic development.

The results showed that the participants referred to nursing care to perform technical procedures, such as vital signs verification, wound and injuries treatment, and medication administration. However, these are understood as only one of the stages of the nursing process, consisting of nursing history, physical examination, nursing diagnosis, nursing care prescription, nursing care evolution and nursing report ${ }^{(13)}$ , a method used by the systematization of nursing care that promotes more autonomy for professionals in their work environments ${ }^{(14)}$. Thus, it is possible to affirm that this perception ends up minimizing the nursing care provided to the worker and the visibility of the attribution of the work nurse in the health of the worker.

In the scope of occupational nursing, this systematization is characterized by the nursing care and measures of the work nurse aiming at systematically promoting, protecting and recovering the health of the worker, through the application of the nursing process $^{(15)}$. It is necessary that its institutionalization is viewed as a work process practice, adequate to the needs of the working community and as a care model to be applied in the assistance to the worker, considering that its implementation effectively improves the quality of care.

Through the variety of activities of an administrative nature referenced by nurses, it was possible to perceive the importance of these activities in their work, evidencing the managerial role of the nurse in the occupational health service of a company. Corroborating this aspect, the occupational nurse is the key to the coordination of a multidisciplinary and holistic approach to safety and quality, comprising occupational and environmental health programs and services, including as one of its attributions, the administration occupational and environmental services of health ${ }^{(6)}$.

Through the educational activities of the nurses, it was possible to visualize two different focuses of purpose, the worker and the nursing team, emphasizing the importance of the educational assignment of the occupational nurses that value the needs of the working community of their company and the team itself, better qualification of professionals and of the assistance provided by the occupational health service. Thus, the practice of health promotion, understood as one of the purposes of health education, has focused on the achievement of well-being through the management of modifiable risk factors, in this case, related to work. In this context, occupational nurses are included as responsible for the implementation of health promotion programs ${ }^{(16)}$.

Integrative activities were highlighted because they were inserted in an intra-institutional context, in the sense of the relationship of nurses with workers and sectors within their company, in addition to the extra-institutional context, their relationship with outsourced companies, organizations and unions. There is evidence of the pervasiveness of the institutional "limits" to perform their duties, meeting the or- 
ganizational needs, which require of their professionals the ability of communication, and the complexity of the health care of the worker, which requires interdisciplinarity. Corroborating, in order to contemplate the health-work relations in all its complexity, it is necessary a multi-professional action, with an interdisciplinary knowledge and an inter-sectorial doing ${ }^{(17)}$.

It is the task of the occupational nurse to investigate the monitoring and analyze episodes and trends of occupational diseases, as well as methods to promote and protect the worker's health and safety ${ }^{(6)}$. Accordingly, research and investigation activities originate from nurses' daily work needs and are carried out in support of their activities, through two types of purposes: the generation of health indicators through periodic reports of occupational health data, which are considered as the result of a research process and the promotion of health by the monitoring of workers with chronic diseases. Therefore, the objective of these activities is not related to the scientific improvement of the nursing area, but rather, it comes from the spontaneous requirement of their work, and there is no programming of the same.

Authors and organizations affirm that the purpose of the work of nurses working in companies is shown by the promotion, prevention, recovery and rehabilitation of workers' health ${ }^{(4,6)}$. However, the results showed that the purpose of the participants' activities goes beyond the worker approach, since nurses are involved, for example, with the integrated management of the occupational health service, with productivity and quality through indicators of health and extra-institutional relationships with outsourced companies, organizations and unions, thus requiring skills and abilities of professionals, which go beyond the attention to the worker.

It was also possible to notice that the legislation permeates the activities of the occupational nurses, since it influences the work organization of the occupational health service and conducts some acti- vities of these professionals. This issue can be visualized through nursing assistance to workers working in confined room and height, the direction of occupational exams of the Occupational Health Medical Control Program, conducting training, integration with other professionals of the Specialized Service in Safety Engineering and in Occupational Medicine and the generation of periodic reports of occupational health. These activities are requirements of the various regulations of the Secretary of Labor and Employment regarding safety and occupational medicine, which shows that nurses must understand the legal parameters of the practice and respond to the legislative mandates that govern attention in this area ${ }^{(6)}$.

\section{Conclusion}

The occupational nurses carry out assistance, administrative, educational, integrative and research activities, where the activities carried out in greater numbers and by the majority of the participants were administrative and educational. Some characteristics of these activities were highlighted in the study, where the professionals do not use the systematization of nursing care in its entirety to assist the workers in an integral way and to value their assistance. Also, the purpose of their work goes beyond the workers' approach, since it is interfered by the characteristics of the occupational health service and the institutional context in which it is inserted, requiring skills and abilities to do so.

\section{Collaborations}

Roloff DIT and Cezar-Vaz MR contributed to the design of the study, analysis and interpretation of the data, critical review of content and approval of the final version to be published. Bonow CA and Mello MCVA contributed in the analysis and interpretation of data and critical review of relevant content. 


\section{References}

1. Costa D, Lacaz FAC, Jackson Filho JM, Vilela RAG. Saúde do trabalhador no SUS: desafios para uma política pública. Rev Bras Saúde Ocup. 2013; 38(127):11-30.

2. Guzik A. Essentials for occupational health nursing. Nova Jersey: John Wiley \& Sons; 2013.

3. Ministério do Trabalho e Emprego (BR). Portaria MTPS no 510, de 29 de abril de 2016: Norma Regulamentadora 4 - Serviços Especializados em Engenharia de Segurança e em Medicina do Trabalho. Brasília: Ministério do Trabalho e Emprego; 2016.

4. Marziale MHP, Hong OS, Morris JA, Rocha FLR. The roles and functions of occupational health nurses in Brazil and in the United States. Rev Latino-Am Enfermagem. 2010; 18(2):182-8.

5. Associação Nacional de Enfermagem do Trabalho. Competências do Enfermeiro do Trabalho [Internet]. 2016 [citado 2016 fev. 07]. Disponível em: http://www.anent.org.br/index.php/anent/ competencias

6. American Association of Occupational Health Nurses.Standards of occupational \&environmental health nursing [Internet]. 2012 [cited 2016 June 3]. Available from: http://paaohn.org/LinkClick. aspx?fileticket=DndRU6CMdtA\%3D\&tabid=98.

7. Lucas AJ. 0 processo de enfermagem do trabalho: a sistematização da assistência de enfermagem em saúde ocupacional. São Paulo: Editora Átria; 2009.

8. Instituto Brasileiro de Geografia e Estatística (BR). Classificação Nacional de Atividades Econômicas Versão 2.0 [Internet]. 2010 [citado 2016 set. 19]. Disponível em: http://cnae.ibge.gov.br/?option $=$ com_tura $\&$ Itemid $=6160 \&$ chave $=\&$ tipo $=c-^{-}$ nae $\&$ versao_classe $=7.0 .0 \&$ versao_subclasse $=9.1 .0$
9. Bardin L. Análise de conteúdo. São Paulo: Edições 70; 2011.

10. Conselho Federal de Enfermagem (BR). Lei no 7.498 de 25 de junho de 1986: Dispõe sobre a regulamentação do exercício da enfermagem, e dá outras providências. Brasília: Conselho Federal de Enfermagem; 1986.

11. Chaves LD, Ramos LH, Figueiredo EN. Job satisfaction of nurses working in Brazil. Acta Paul Enferm. 2011; 24(4):507-13.

12. Fernandes RCP, Assunção AA, Carvalho FM. Mudanças nas formas de produção na indústria e a saúde dos trabalhadores. Ciênc Saúde Coletiva. 2010; 15(1):1563-74.

13. Conselho Federal de Enfermagem (BR). Resolução no 358 de 15 de outubro de 2009: dispõe sobre a Sistematização da Assistência de Enfermagem e a implementação do Processo de Enfermagem em ambientes, públicos ou privados, em que ocorre o cuidado profissional de Enfermagem, e dá outras providências. Brasília: Conselho Federal de Enfermagem; 2009.

14. Ferreira EB, Pereira MS, Souza ACS, Almeida CCOF, Taleb AC. Systematization of nursing care in the perspective of professional autonomy. Rev Rene. 2016; 17(1):86-92.

15. Silva ARS, Souza KRF, Bezerra MPM, Arruda CB, Lima CR, Oliveira JS. Sistematização da assistência de enfermagem em trabalhadores com distúrbios osteomusculares. Semina Cienc Biol Saúde. 2014; 1(3):35-45.

16. Dombrowski JJ, Snelling AM, Kalicki M. Health promotion overview - evidence-based strategies for occupational health nursing practice. Workplace Health Saf. 2014; 62(8):342-9.

17. Lino MM, Nora PT, Lino MM, Furtado M. Enfermagem do trabalho à luz da visão interdisciplinar. Saúde Transform Soc. 2012; 3(1):85-91. 